\title{
Surrogate Experiential Learning-Based Science Subject Specific Pedagogy (SSP) to Build Disaster Preparedness of Junior High School Students on Volcanic Eruption
}

\author{
Widodo Setiyo Wibowo $^{1 *}$, Sabar Nurohman ${ }^{2}$, Allesius Maryanto ${ }^{3}$ \\ 1,2,3 Department of Science Education, Faculty of Mathematics and Natural Sciences, Universitas Negeri \\ Yogyakarta, Jl. Kolombo No. 1 Yogyakarta, Indonesia \\ Corresponding Author. Email: widodo_setiyo@uny.ac.id
}

\begin{tabular}{l}
\hline Keywords: \\
disaster \\
preparedness, SSP, \\
surrogate \\
experiential \\
learning, volcanic \\
eruption.
\end{tabular}

\begin{abstract}
The study was conducted to develop surrogate experiential learning (SEL)-based science Subject Specific Pedagogy (SSP) that is feasible to be implemented in science learning and potentially to build volcanic eruption disaster preparedness of junior high school students. The study was Research and Development (R\&D), modified from Borg \& Gall steps covering only research and information collecting, planning, preliminary form of product development, expert judgment, product revision, and final product. The subjects were 2 expert lecturers (content expert and media expert) and 2 science teachers of SMP N 2 Cangkringan. The types of data were quantitative and qualitative. Data were collected by means of SSP validation sheets and disaster preparedness identification sheets. The techniques of data analysis were descriptive analysis of qualitative and quantitative to 5 grading scale. The result of the study shows that SEL-based science SSP is feasible to be implemented in science learning and potential to build volcanic eruption disaster preparedness of junior high school students.
\end{abstract}

C2018 JSER. Yogyakarta State University.

\section{INRODUCTION}

Geologically, Indonesia is located on the ring of fire area, so most of Indonesian islands have active volcanoes and erupt rapidly. The Special Region of Yogyakarta (DIY) has Mount Merapi, the most active volcano in the world. It has a very high level vulnerability to hazards because according to modern records, it erupts every two to five years and surrounded by a very dense settlement. Reflecting at the huge eruptions that occurred in the year 2010, based on data from the Badan Nasional Penanggulangan Bencana (BNPB) as reported by the kompas.com 09/11/2010 edition, the number of victims who died from Merapi eruption since Oct. 26 had reaching 151 people consisting of 135 people in DIY and 16 people in Central Java. It also destroyed 291 houses and resulted refugees almost 320,090 inhabitants.
Natural hazard can cause enormous calamity in multiple ways such as physical, psychological and financial that affect people at all levels (Maharani, Lee, Ki, 2016:63). Pedro Bastidas \& Marla Petal (2012: 9) stated that disasters have a major impact on children, youth and education systems. In many cases of disasters in various parts of the world, disasters resulting in injury and even death in students, teachers and educational personnel. According to the International Federation of the Red Cross and Red Crescent Societies (2006), every year in the world, about 175 million school-age children affected by natural disasters. In addition, many school facilities damaged as school building collapse, and various other supporting facilities. The data is certainly small portraits to illustrate how a disaster providing impact and tremendous losses. If it is accumulated with any other disaster as well as in the different years, then the resultant loss would be much greater. 
Looking at such data, efforts to minimize the risk of disaster are important to be executed. World Conference on disaster risk Reduction Efforts in 2005 yielded the "Framework of Action" Hyogo 2005-2015, with the theme of "Building The Resilience of Countries and Communities Against Disasters" adopt the priority actions, such as using knowledge, innovation, and education to build a culture of safe and resilience at all levels, as well as strengthen disaster preparedness for effective response at all levels (ISDR, 2005). In an effort to reduce the risk of disaster, there are three stakeholders namely individuals and households, government, and school community (Deny Hidayati, et.al., 2006: 2). The role of the schools are important because they act as a source of knowledge and agent to disseminate knowledge about disaster to the students. It is based that the children have specific vulnerabilities and needs to be addressed in risk reduction and they have the capacity for active participation in risk identification, risk reduction, preparedness and response (Benson $\&$ Bugge, 2008). Therefore, schools through a process of disaster risk reduction education (DRRE) are responsible for enhancing the student capacity to deal with disasters. Ultimately, through this process, students expected to be agents that will disseminate this knowledge to their family, community, environment and creates a community-based preparedness. Disaster preparedness is a condition of society having ablility to anticipate disasters that is possible to happen in certain time (Gregg et al., 2004; Sutton \& Tierney, 2006).

If we look further, unfortunately, DRRE has not been much done in Indonesian schools, as well as in DIY. Based on the results of interviews with some teachers, they stated that they did not understand how to integrate it into curriculum and instruction. In addition, they feel didn not yet have adequate knowledge to teach the material on disaster topic. However, according to Marla Petal (2008), DRRE can be integrated in curricular activities on all subjects and in extracurricular activities. He further stated that the earliest roots of disaster risk reduction education are found in science and geography education throughout the world, addressing the so-called "natural" hazards such as earthquakes, volcanoes, floods, landslides and tsunamis. Science learning become one of a potential subjects to be integrated with DRRE.
According to the Depdiknas (2008), science is closely related to the way of finding out about nature systematically. Science education expected to become a media for students to learn about ourselves and the natural surroundings, as well as being able to apply it in real life. This implies that science learning is potential to be integrated with DRRE, for the disaster is one of the natural phenomena studied in science. Thus, through science learning, disaster phenomena can be examined comprehensively in a review of the concept of physics, biology, chemistry, and other fields such as environmental science and also geology. Environmental science, geography, and geology discuss geological disaster-related phenomena such as earthquakes, tsunamis, volcanic eruptions, and others. By integrating it into science learning, then it is not only able to achieve cognitive competence, but also disaster preparedness.

To realize the science learning integrating DRRE, it requires appropriate learning modalities. Recommended learning modalities for that revolutionized DRRE is interactive learning, a pedagogical manifestation of child participation rights mentioned in the Convention on The Rights of The Child. There are several appropriate learning modalities for disaster risk reduction education, namely, interactive learning, affective learning, inquiry learning, surrogate experiential learning, field experiential learning, action learning, as well as imaginal learning (Kagawa \& Selby, 2012). One of the modalities that can be applied is surrogate experiential learning (SEL). Experiential learning refers to making meaning from direct experience (Mughal \& Zafar, 2011: 28). SEL is a modification of experiential learning, in which the experience is presented in the form of imitation. It is based on the fact that it is impossible to present the disaster phenomena in the real context because it is not happen every time. Therefore, it should be replaced with a mock object, model, or simulation which represents the real facts. The specificity of the SEL is the presence of a real learning experience. It gives the opportunity to students to interact directly with object learned. Object or phenomenon regarding disaster that is difficult to be served in the classroom can be presented in the form of duplicate instruments so that students gain a deep understanding. Thus, the use of SEL is a proper way to pack the material and achieve the expected goals. 
To support the success of the integration of DRR in science teaching needed a complete and comprehensive guide to direct the teachers and students on purpose. Teachers should have access to a variety of learning resources, as well as guidance and learning devices (Avianto Amri et.al., 2017: 609). One of the guides that can be used is a subject specific pedagogy (SSP). The existence of SSP able to provide guidance for teachers in guiding student learning activities become more focused. Unfortunately, SSP is not yet widely available. Based on observation, most of science teachers hasn't been able to compile SSP independently. Therefore, they use the teacher book and student book giving less emphasis on disaster preparedness. Therefore, it is essential to develop science Subject Specific Pedagogy (SSP) based on Surrogate Experiential Learning to develop disaster preparedness of junior high school students on volcanic eruption. Based on the problems, the purpose of this study was to develop surrogate experiential learning (SEL)-based science Subject Specific Pedagogy (SSP) that is feasible to be implemented in science learning and potentially to build volcanic eruption disaster preparedness of junior high school students.

\section{METHODS}

The study was research and development $(R \& D)$, since it was a process used to develop and validate educational product (Borg and Gall in Dadan Rosana and Sukardiyono, 2017: 18). The development model used refered to the main steps of Borg \& Gall (1983: 775) with a few adjustments. The steps covered only research and information collecting, planning, a preliminary form of product development, expert judgment, product revision, and the final product. The subjects were 2 expert lecturers (content expert and media expert) and 2 science teachers of SMP N 2 Cangkringan. The types of data were quantitative and qualitative. Data were collected by means of SSP validation sheets and disaster preparedness identification sheets. The techniques of data analysis were descriptive analysis of qualitative and quantitative to 5 grading scale. Suggestions were selected to be used as a basis for improvements to the SSP, while scores were analysed with steps as follows: (1) tabulate all data obtained from the validator for each component of the assessment, (2) calculate the average score of each component, and (3) convert the average score into a value with criteria according to Saifudin Azwar (2011: 163). Reference of score conversion is presented in Table 1.

Table 1. Score conversion reference into value with criteria

\begin{tabular}{cc}
\hline Scores Range & Category \\
\hline $\mathrm{X}>\mathrm{Mi}+1.5 \mathrm{Sbi}$ & Excellent \\
$\mathrm{Mi}+0.5 \mathrm{Sbi}<\mathrm{X} \leq \mathrm{Mi}+1.5 \mathrm{Sbi}$ & Very Good \\
$\mathrm{Mi}-0.5 \mathrm{Sbi}<\mathrm{X} \leq \mathrm{Mi}+1.5 \mathrm{Sbi}$ & Good \\
$\mathrm{Mi}-0.5 \mathrm{Sbi}<\mathrm{X} \leq \mathrm{Mi}-1.5 \mathrm{Sbi}$ & Fair \\
$\mathrm{X}<\mathrm{Mi}-1.5 \mathrm{Sbi}$ & Poor \\
\hline
\end{tabular}

Description:

$$
\begin{aligned}
\mathrm{X} & =\text { actual score } \\
\mathrm{M} & =\text { ideal score average } \\
& =(1 / 2) \text { (ideal highest score }+ \text { ideal } \\
& \text { lowest score }) \\
\mathrm{s} & =\text { ideal standard deviation } \\
& =(1 / 2)(1 / 3) \text { (ideal highest score - ideal } \\
& \text { lowest score })
\end{aligned}
$$

Ideal highest score $=\sum$ criteria item $\mathrm{x}$ highest score

Ideal lowest score $=\sum$ criteria item $\mathrm{x}$ lowest score

The SSP is feasible to be used in science learning if each component has "very good" category.

\section{RESULTS}

\section{Feasibility of Science SSP based on SEL}

Result of the preliminary studies shows that in DIY, there are a few of junior high school lies in affected areas of a volcanic eruption, whereas students have not had good awareness about vulnerability in their region. Viewed from the side of teachers, many of them do not understand how to integrate disaster risk reduction into science teaching. Therefore, the DRRE is essential to be implemented to reduce the risk of such disasters. In the content standard of 2013 Curriculum (K13), there is a basic competence (KD) at the grade 7 th that discusses about the structure of earth and its relation to geological disasters such as eruptions, tsunamis, and earthquakes explicitly. This topic is potential for not only enrich students' knowledge but also to develop the students' preparedness in facing volcanic eruptions.

Based on preliminary study, it is determined that selected product to be developed is SSP. It is based on the 
consideration SSP is both complete and comprehensive to guide teachers in teaching science materials which have a specific purpose, such as to develop disaster preparedness of students. The SSP consists of some components, i.e. the syllabus, lesson plan, worksheets, questionnaire and observation sheets. The selected format in developing syllabus and lesson plan refers to Permendikbud No. 22 Tahun 2016, while student worksheet refers to Depdiknas (2005: 4). However, Permendikbud
No. 23 Tahun 2016 is refered as a format of questionnaire and observation sheets.

Draft of SSP is validated by content experts, media experts and science teachers. Validation is expected to give advices for the improvement of the SSP as well as giving a score to determine the quality criteria of the SSP. Results of SSP quality assessment by experts and teachers are presented in Table 2 below.

Table 2. The results of SSP quality assessment

\begin{tabular}{lcccc}
\hline \multirow{2}{*}{ Component of SSP } & \multicolumn{2}{c}{ Expert/ lecturer $(\mathbf{N}=\mathbf{2})$} & \multicolumn{2}{c}{ Teacher $(\mathbf{N}=\mathbf{2})$} \\
\cline { 2 - 5 } & Score & Category & Score & Category \\
\hline Syllabus & 3.88 & Excellent & 3.94 & Excellent \\
Lesson plan & 3.88 & Excellent & 4.00 & Excellent \\
Student worksheet & 3.87 & Excellent & 3.94 & Excellent \\
Questionnaire & 3.88 & Excellent & 4.00 & Excellent \\
Observation sheet & 3.88 & Excellent & 4.00 & Excellent \\
\hline
\end{tabular}

Besides, experts and teachers also give comments and suggestions to improve the SSP as follow in Table 3.

Table 3. The comments and suggestions of experts and teachers toward SSP

\begin{tabular}{ll}
\hline Component of SSP & \multicolumn{1}{c}{ Comment and Suggestions } \\
\hline Syllabus & $\begin{array}{l}\text { Use active form sentences in expressing learning experience } \\
\text { Ripening media used as a substitute for real experience }\end{array}$ \\
\hline Lesson plan & $\begin{array}{l}\text { Render the material in points and just attach the full materials } \\
\text { Use active form sentences in expressing learning steps } \\
\text { Clarified description of the video or practical at reflective observation phase } \\
\text { Degree need to be added on the learning objectives } \\
\text { Add "motivation" and "delivery of learning objectives" activities in preliminary } \\
\text { activities } \\
\text { Make several stages of learning more systematic according to the syntax of SEL }\end{array}$ \\
\hline Student worksheet & $\begin{array}{l}\text { Questions on worksheets need to be supplemented by comparing and analysing aspect } \\
\text { Images that looks blurry and unclear need to be corrected and annotated } \\
\text { Need real pictures about volcanic eruption }\end{array}$ \\
\hline Questionnaire & $\begin{array}{l}\text { Preferably positive statements collected by the positive and negative to negative in } \\
\text { order to make it easier to be analyzed } \\
\text { Some sentences need to be improved to make it more easily understood }\end{array}$ \\
\hline Observation sheet & $\begin{array}{l}\text { Items of the statement in knowledge and attitude towards disaster risk aspect are made } \\
\text { in detail and provided examples of eruption signs, character, and threats in order to } \\
\text { facilitate observer }\end{array}$ \\
\end{tabular}


Table 2 shows that all of components of SSP are categorized as "excellent". Syllabus and lesson plan have "excellent" category. Experts and teachers declare that competences and indicators have been formulated in accordance with K13. Subject matter has also been elaborated appropriate to competences and indicators. In terms of learning experience and learning model selection, activities have reflected SEL steps and supports on the disaster preparedness achievement. Time allocation provided stated clearly and suitable for the demands of the indicators. Furthermore, assessments are suitable for competences and indicators and use appropriate techniques and instruments. Learning resources and media used in accordance with the activities and subject matter as well as the surrogate. Finally, linguistic aspects have also been used in accordance with the EYD and easily understood.

Student worksheet validation includes three aspects, namely suitability of content, suitability of construction, and suitability of technical. Suitability of content aspect is categorized as "excellent". This means that materials presented in worksheet have compatibility with competences. In terms of concept truth, almost all of the concepts in accordance with the applicable definitions in the field of science, do not give a lot of interpretations, and do not effect misconceptions. The materials also have appropriate alignment between earth science and biology. Almost all of the facts presented are suitable to reality, right, and do not force the will and do not conflict with the previous facts. In addition, the activities in the worksheet support students to learn actively as well as cause a pleasant atmosphere. The existence of elements and syntax of SEL, aspects of disaster preparedness and correlation between them are main identifier this aspect. All of SEL steps have been formulated in learning activities. Assignments and activities can encourage students to develop all aspects of disaster preparedness.

Suitability of construction requirements aspect is rated "excellent" by the experts and teachers. It indicates that most of languages used in the worksheet in accordance with the level of students development, simple, systematic, and easy to be understood, although there are a few of typo. Almost all of sentences in accordance with enhanced spelling (EYD) and do not give rise to a double interpretation. Questions are stated in clear language and help students in drawing conclusions. Discussion and experiment activities use not harmful tools and materials and easily obtained. Furthermore, procedures are presented clearly, coherently, and easy to be understood.

The last aspect is the suitability of technical requirements. As in other aspects, experts and teachers give "excellent" category in this aspect. The use of the typeface, font size, spacing and number of lines per page are suitable. Attractiveness of display is fulfilled by using of display design, color combinations, as well as interesting lay out, systematic, and organized in neat. In General, illustrations, graphics, pictures, photographs presented on the worksheet are in accordance with the concept, clear, interesting, and colorful, though there are several illustrations should be clarified further and given a description in order to be easily understood.

There are four aspects validated in both questionnaire and observation sheet, namely instructions, scope of content, language, and writing. According to experts and teachers, the qualities of those aspects are categorized as "excellent". This is relevant since the initial part of the questionnaire and observation sheet contain instructions and scoring criteria. On the scope of content, all statements and observation items have been covering all aspects of disaster preparedness, measurable, and clearly defined. The language used in drafting the statement is easy to understand, simple, according to EYD, and not ambiguous. Meanwhile, there are only a few languages in sentences that need to be improved to make it more easily understood. In writing aspect, the use of numbers, letters, punctuation, and symbols are appropriate.

Though the quality of SSP is categorized as "excellent", but it still needs a minor revision according to the comments and suggestions. Revision will obtain a final SSP. All in all, it can be said that SSP is feasible to be used in science learning.

\section{The potency of SSP in developing disaster preparedness}

In this study, there are four aspects of disaster preparedness used, namely knowledge and attitudes towards disaster risk, early warning systems, plans for emergency response, and ability to mobilize resources (Deny Hidayati et.al., 2006: 14; BNPB, 2012: 29-35). In order SSP has potency to develop disaster 
preparedness, it needs to integrate these aspects into the SSP. All aspects can be integrated through learning activities arranged with SEL syntaxes. There are four phase of SEL syntax adopted from Kolb (1984: 25), i.e. surrogate experience, reflective observation, abstract conceptualization, and active experiment. As for correlation between SEL syntax and disaster preparedness aspects are described in Table 4.

To ensure appearance of disaster preparedness aspects in the SSP, the validation of experts was applied. The results of experts validation presented in Table 5.

Table 4. The correlation between SEL syntax and disaster preparedness aspects

\begin{tabular}{ll}
\hline \multicolumn{1}{c}{ The Syntax of SEL } & \multicolumn{1}{c}{ Aspects of disaster preparedness } \\
\hline Surrogate experience & Knowledge and attitudes towards disaster risk \\
\hline Reflective observation & Knowledge and attitudes towards disaster risk \\
\hline Abstract conceptualization & Knowledge and attitudes towards disaster risk \\
\hline Active experiment & a) Knowledge and attitudes towards disaster \\
& $\begin{array}{l}\text { risk } \\
\text { b) Early warning systems } \\
\text { c) Plans for emergency response } \\
\text { d) Ability to mobilize resources }\end{array}$ \\
\hline
\end{tabular}

Table 5. Validation result of integrating disaster preparedness aspects into SSP

\begin{tabular}{|c|c|c|c|}
\hline \multirow{2}{*}{ Component } & \multirow{2}{*}{ Aspects } & \multicolumn{2}{|c|}{ Existence/ potency } \\
\hline & & Yes & No \\
\hline \multirow[t]{6}{*}{ Syllabus } & $\begin{array}{l}\text { Integrating competences associated with disaster (KD 3.8, 3.10, and } \\
4.10)\end{array}$ & $\sqrt{ }$ & \\
\hline & $\begin{array}{l}\text { Formulating indicators that become benchmarks of achievement of } \\
\text { disaster preparedness }\end{array}$ & $\sqrt{ }$ & \\
\hline & $\begin{array}{l}\text { Selecting subject matter that supports the disaster preparedness } \\
\text { achievement }\end{array}$ & $\sqrt{ }$ & \\
\hline & $\begin{array}{l}\text { Learning activities based on the syntax of the SEL supports the } \\
\text { achievement of disaster preparedness of students }\end{array}$ & $\sqrt{ }$ & \\
\hline & $\begin{array}{l}\text { Using techniques and forms of instrument that proper to measure } \\
\text { disaster preparedness aspect }\end{array}$ & $\sqrt{ }$ & \\
\hline & $\begin{array}{l}\text { Using learning resources that is both surrogate and supports } \\
\text { achievement of disaster preparedness aspect }\end{array}$ & $\sqrt{ }$ & \\
\hline \multirow[t]{7}{*}{ Lesson plan } & $\begin{array}{l}\text { Integrating basic competences (KD) associated with disaster (KD 3.8, } \\
3.10 \text {, and } 4.10 \text { ) }\end{array}$ & $\sqrt{ }$ & \\
\hline & $\begin{array}{l}\text { Formulating learning objectives and indicators as benchmarks of } \\
\text { disaster preparedness achievement }\end{array}$ & $\sqrt{ }$ & \\
\hline & $\begin{array}{l}\text { Outlining the learning materials supporting the disaster preparedness } \\
\text { achievement }\end{array}$ & $\sqrt{ }$ & \\
\hline & $\begin{array}{l}\text { SEL model is in accordance with the modalities of learning that } \\
\text { supports Disaster Risk Reduction Education (DRRE) }\end{array}$ & $\sqrt{ }$ & \\
\hline & $\begin{array}{l}\text { Using the media and learning resources that are surrogate and supports } \\
\text { achievement of the disaster preparedness }\end{array}$ & $\sqrt{ }$ & \\
\hline & $\begin{array}{l}\text { Steps of learning refers to the syntax of the SEL supporting the } \\
\text { achievement of disaster preparedness }\end{array}$ & $\sqrt{ }$ & \\
\hline & $\begin{array}{l}\text { Using techniques and forms of instrument that proper to measure } \\
\text { disaster preparedness aspect }\end{array}$ & $\sqrt{ }$ & \\
\hline \multirow[t]{3}{*}{$\begin{array}{l}\text { Student } \\
\text { worksheet }\end{array}$} & $\begin{array}{l}\text { Formulating goals as a benchmark of disaster preparedness } \\
\text { achievement in worksheet } 1,2,3 \text {, and } 4\end{array}$ & $\sqrt{ }$ & \\
\hline & $\begin{array}{l}\text { Using tools and materials supporting the achievement of disaster } \\
\text { preparedness in worksheet } 1,2,3 \text {, and } 4\end{array}$ & $\sqrt{ }$ & \\
\hline & $\begin{array}{l}\text { Steps of learning refers to the syntax of the SEL supporting the } \\
\text { achievement of disaster preparedness in worksheet } 1,2,3 \text {, and } 4\end{array}$ & $\sqrt{ }$ & \\
\hline
\end{tabular}




\begin{tabular}{lll}
\hline Questionnaire & There are statements representing knowledge and attitude towards & $\sqrt{ }$ \\
& disaster risk aspect & $\sqrt{ }$ \\
\cline { 2 - 3 } & There are statements representing early warning system aspect & $\sqrt{ }$ \\
\cline { 2 - 3 } & There are statements representing plans for emergency response aspect & $\sqrt{ }$ \\
\cline { 2 - 3 } $\begin{array}{l}\text { There are statements representing resource mobilization aspect } \\
\text { sheet }\end{array}$ & $\begin{array}{l}\text { There are items of observation representing knowledge and attitude } \\
\text { towards disaster risk aspect }\end{array}$ & $\sqrt{ }$ \\
\cline { 2 - 3 } & There are items of observation representing early warning system & $\sqrt{ }$ \\
& $\begin{array}{l}\text { Thect } \\
\text { response aspect }\end{array}$ & $\sqrt{ }$ \\
\hline & $\begin{array}{l}\text { There are items of observation representing resource mobilization } \\
\text { aspect }\end{array}$ & $\sqrt{ }$ \\
\end{tabular}

Table 5 illustrates the correlation between SEL syntax with four aspects of disaster preparedness. There are 4 phase in SEL. Sharlanova (2004: 37-38) said that surrogate experience contains activities based on a previous experience either in formal or informal. This phase emphasize on interaction of students with their environment as well as generate information involving feelings. Therefore, the aspect of knowledge and attitude towards disaster risk can be achieved from this stage. Reflective observation phase contains activities reminding experience given earlier, observing experience, and reporting everything observed. Next, the students reflect on his experience and draw a lesson from the reflection phase, so that aspect of knowledge and attitude towards disaster risk can be achieved from this stage.

Abstract conceptualization phase is also able to bridge the achievement of knowledge and attitude toward disaster risk aspect because this stage contains activities of searching for reasons and the relationship of reciprocity of the experience acquired, then conceptualizing the experience acquired with the material or theories that have already studied. The active experiment phase contains activities of planning how to test the efficacy of a model or theory to explain a new experience or new problem that will be acquired next. Thus, all of aspects of disaster preparedness will be acquired.

Table 6 describes the appearance of disaster preparedness aspect in each of SSP component. In syllabus and lesson plan, it appears from integration of competences associated with disaster (KD 3.8, 3.10, and 4.10), formulation of indicators and goals of disaster preparedness achievement, and description of learning material. The SEL model used also in accordance with the modalities of learning that supports Disaster Risk Reduction
Education (DRRE). The use of surrogate media and learning resources, learning steps refer to the syntax of the SEL, as well as the use of techniques and forms of instrument are proper to support and measure the disaster preparedness aspect.

In worksheet, disaster preparedness aspect appears on formulation of purpose of activities becoming benchmarks of disaster preparedness achievement, the use of tools and materials, as well as learning steps refer to the syntax of SEL. Furthermore, in questionnaire and observation sheet, disaster preparedness aspects seen clearly in the statements and observation items representing aspects of the knowledge and attitude to disaster risk, early warning systems, plans for emergency response, as well as the mobilization of resources. Finally, it can be concluded that SSP has a potential to develop volcanic eruption disaster preparedness of junior high school students.

\section{CONCLUSIONS}

Based on the results and discussion above, it can be concluded that SEL-based science SSP has been developed and all of SSP components are rated as excellent category. That is why it is feasible to be implemented in science learning and has potential to build volcanic eruption disaster preparedness of junior high school students.

\section{REFERENCES}

Avianto Amri et.al. (2017). Disaster risk reduction education in Indonesia: challenges and recommendations for scaling up. Journal of Natural Hazards Earth System Science, 17, 595 - 612. 
Benson, Lynne \& Jon Bugge. (2008). Child-Led Disaster Risk Reduction - A Practical Guide, Save the Children. Thailand. http://www.eldis.org/assets/Docs/38480.h tml

BNPB. (2012). Peraturan Kepala Badan Nasional Penanggulangan Bencana No. 04 Tahun 2012 tentang Pedoman Penerapan Sekolah/ Madrasah Aman dari Bencana. Jakarta.

Borg, W. R., \& Gall, M. D. (1983). Educational Research: An Introduction (4th ed.). New York \& London: Longman Inc.

Dadan Rosana \& Sukardiyono, (2017). Development of integrated education management information system as the database of education budget policy formulation. Journal of Science Education Research, 1(1), 1-17.

Deny Hidayati, dkk. (2006). Kajian Kesiapsiagaan Bencana Masyarakat dalam Menghadapi Bencana Gempa dan Tsunami. Jakarta: LIPI-UNESCO-ISDR.

Depdiknas. (2008). Panduan Pengembangan Pembelajaran IPA Terpadu SMP/MTs. Jakarta: Puskur-Balitbang Depdiknas.

Depdiknas. (2005). Pedoman penyusunan LKS SMA (versi elektronik). Jakarta: Depdiknas.

Gregg, C. E., Houghton, B. F., Johnston, D. M., Paton, D., and Swanson, D. A. (2004). The Perception of Volcanic Risk in Kona Communities from Mauna Loa and Hualalai Volcanoes, Hawaiki. Journal of Volcanology and Geothermal Research, 130, 179-196.

The International Federation of the Red Cross and Red Crescent Societies World Disasters Report. (2006). "Legacy of disasters-The impact of climate change on children". Save the Children.

ISDR. (2005). Hyogo 2005-2015 Action framework. World Conference of Disaster
Reduction . 18-22 January, Kobe, Hyogo, Japan

Kagawa, F. \& Selby, D. (2012). Disaster Risk Reduction in the School Curriculum: Cast Studies from Thirty Countries. Geneva: UNICEF/UNESCO.

Kolb, D. A. (1984). Experiential Learning: Experiences as a source of learning and development. Englewood Cliffs, NJ: Prentice-Hall

Kompas. (2010). Letusan Merapi. Diakses pada $27 \quad$ November $2010 . \quad$ dari http://regional.kompas.com/read/2010/11/ 09/15573541/Erupsi.Merapi.2010.Lebih. Besar.Dari.1872.

Marla Petal. (2008). Disaster Prevention for Schools Guidance for Education Sector Decision-Makers. Geneva: UNISDR.

Mughal, Farooq \& Aneesa Zafar. (2011). Experiential Learning from a Constructivist Perspective: Reconceptualizing the Kolbian Cycle. International Journal of Learning \& Development, 1 (2), 27-37.

Pedro Bastidas \& Marla Petal. (2012). Assessing School Safety from Disasters - A Global Baseline Report. Geneva: UNISDR.

Permendikbud No. 22 tahun 2016 tentang Standar Isi.

Permendikbud No. 23 tahun 2016 tentang Standar Penilaian.

Saifuddin Azwar. (2011). Metode Penelitian. Yogyakarta: Pustaka Pelajar.

Sharlanova, Valentina. (2004). Experiential Learning. Trakia Journal of Sciences, 2(4), 36-39.

Sutton, J., and Tierney, K. (2006). Disaster Preparedness: Concepts, Guindance and Research. Colorado: University of Colorado.

Y. N. Maharani, S. Lee, \& S. J. Ki. (2016). Social vulnerability at a local level around the Merapi volcano. International Journal of Disaster Risk Reduction 20, 63-77 